\title{
Evaluation of Childhood Posterior Fossa Malignant Tumors: A Single-center Study
}

\section{Çocukluk Çağı Arka Çukur Habis Tümörlerinin Değerlendirilmesi: Tek Merkezli Çalışma}

\author{
(D) Burak Eren, (DI İlker Güleç, (D) Nuri Serdar Baş
}

University of Health Sciences Turkey, Bağcllar Training and Research Hospital, Clinic of Neurosurgery, İstanbul, Turkey

\section{Abstract}

Objective: The aim of this study is to determine the clinical and radiological findings, early surgical results, and complication rates of children who were admitted to the neurosurgery clinic due to the posterior fossa malignant tumor.

Method: The records of patients under the age of 18 who were diagnosed as malignant posterior fossa tumors in our clinic between 2011-2020 were scanned. The demographic features, symptoms, signs, surgeries, pathological results, and complications of the patients were recorded. Pre and postoperative neuroimaging of patients are examined; The location of the tumor, the presence of a residual tumor and of hydrocephalus were examined.

Results: Thirty-three patients were identified, the median age of these children was 7. Among the symptoms of admission were headaches (57.6\%) and gait disturbance (48.5\%). Papilledema, ataxia, and nystagmus were also common. Six patients had preoperative cranial nerve palsy and 3 patients had hemiparesis. Preoperative hydrocephalus was present in $66.7 \%$. The most common tumor type was medulloblastoma (39.4\%). The rate of high-grade tumors among the operated tumors was $66.7 \%$. Seven of the resected tumors had invasion into the brain stem. Tumor resection was performed in 24 patients, in 12 patients total resection was achieved. Tumor surgery was not performed in patients with diffuse pontine glioma. External ventricular drainage (EVD) was inserted in $30.3 \%$ of all patients. Only 4 of them needed ventriculoperitoneal (V-P) shunt. Highgrade tumors had a higher risk of complications than low-grade tumors $(p=0.038)$. The complication rate was high in totally removed tumors $(p=0.034)$. The most common complication was CSF fistula $(16.7 \%)$. Three patients with EVD had signs of infection. Three patients had a hematoma at the postoperative tumor site. Hydrocephalus developed in two patients without EVD and V-P shunts were inserted to these patients. Four of 6 patients with $\mathrm{V}$-P shunt inserted had postoperative intraventricular blood. Postoperative hemiparesis was observed in two

\section{Öz}

\begin{abstract}
Amaç: Arka çukur habis tümörleri nedeniyle nöroşirurji kliniğine yatırılan çocukların klinik ve radyolojik bulguları ile birlikte erken cerrahi sonuçları ve komplikasyon oranlarının belirlenmesi amaçlanmıştır.
\end{abstract}

Yöntem: 2011-2020 yılları arasında kliniğimizde malign posterior fossa tümörü tanısıyla tedavi olan 18 yaş altındaki hastaların verileri tarandı. Hastaların demografik özellikleri, şikayetleri, klinik bulguları, yapılan ameliyatlar, patoloji sonuçları ve komplikasyonlar not edildi. Ameliyat öncesi ve sonrası görüntüleme yöntemleri incelendi. Tümörün yerleşim yeri, rezidü tümör varlığı, hidrosefali olup olmamasına bakıldı.

Bulgular: Otuz üç hasta tespit edildi, bu çocukların ortanca yaşı 7 idi. Başvuru şikayetleri arasında en fazla baş ağrısı $(\% 57,6)$ ve dengesizlik $(\% 48,5)$ vardı. Papilödem, ataksi ve nistagmus ön planda idi. Ameliyattan önce 6 hastada kranial sinir paralizisi ve 3 hastada hemiparezi vardı. Ameliyat öncesi hidrosefali \%66,7'sinde vardı. En fazla görülen tümör medulloblastomdu $(\% 39,4)$. Opere edilen tümörler içinde yüksek dereceli tümör oranı \%66,7 idi. Rezeksiyon yapılan tümörlerden 7 tanesinde beyin sapına invazyon görüldü. Yirmi dört hastaya tümör rezeksiyonu yapıldı, bunların 12'sinde total çıkarım sağlandı. Diffüz pontin gliom olan hastalara cerrahi yapılmadı. Tüm hastaların \%30,3'üne eksternal ventriküler drenaj (EVD) takıldığı tespit edildi. Bunlardan sadece 4'ünün ventriküloperitoneal (V-P) şant ihtiyacı oldu. Yüksek dereceli tümörlerde herhangi bir cerrahi komplikasyon gelişme oranı düşük dereceli tümörlere göre daha fazlaydı $(p=0,038)$. Total çıkarılan tümörlerde de komplikasyon oranı yüksekti $(p=0,034)$. En fazla görülen komplikasyon BOS fistülüydü (\%16,7). EVD'si olan 3 hastada enfeksiyon bulguları vardı. Üç hastada tümör lojunda hematom vardı. EVD'si olmayan iki hastada $(\% 8,3)$ hidrosefali gelişti ve bu hastalara V-P şant takıldı. Şant takılan 6 hastadan 4'ünde ameliyat sonrası ventrikül içinde kan vardı. Daha önce güçsüzlüğü olmayan iki hastada ameliyattan sonra hemiparezi gelişti. Üç hastada $(\% 12,5)$ mutizm ve bir hastada dizartri vardı. İki hastada yoğun bakım takibi sırasında pnömoni gelişti ve bu çocuklardan biri ameliyattan sonra ikinci ayda kaybedildi.

Address for Correspondence: Burak Eren, University of Health Sciences Turkey, Bağcılar Training and Research Hospital, Clinic of Neurosurgery, İstanbul, Turkey

E-mail: drburakeren@hotmail.com ORCID: orcid.org/0000-0001-5554-2585 Received: 06.07.2020 Accepted: 05.08.2020

Cite this article as: Eren B, Güleç İ, Baş NS. Evaluation of Childhood Posterior Fossa Malignant Tumors: A Single-center Study. Bagcilar Med Bull 2020;5(3):116-122

(C) Copyright 2020 by the Health Sciences University Turkey, Bagcilar Training and Research Hospital Bagcilar Medical Bulletin published by Galenos Publishing House. 


\section{Abstract}

patients without previous weakness. Three patients (12.5\%) had mutism and one patient had dysarthria. Two patients had pneumonia during intensive care follow-up and one of these children died two months later.

Conclusion: In children with posterior fossa malignant tumors; We found that a high degree of the tumor, brainstem invasion, complete removal of the tumor, and presence of postoperative blood in the ventricle increase the risk of complications.

Keywords: Chilhood malignant tumors, complication, pediatric brain tumors, posterior fossa tumors

\section{Öz}

Sonuç: Çocukluk çağı arka çukur habis tümörlerinde, yüksek dereceli tümör varlığı, beyin sapı invazyonu, tümörün total çıkarılması ve ameliyat sonrası ventrikül içinde kan olması komplikasyon riskini artırmaktadır.

Anahtar kelimeler: Çocukluk çağı malign tümörleri, komplikasyon, pediyatrik beyin tümörü, posterior fossa tümörü

\section{Introduction}

Malignant central nervous system tumors are the second most common malignancies in children after leukemia and they are the most common pediatric solid organ tumors (1). The proportion of tumors located in the posterior fossa in childhood is between $54 \%$ and $70 \%$ and higher than in adults (2). Symptoms and signs of posterior fossa tumors are primarily due to increased intracranial pressure and secondary to local compression of cerebellar nuclei and brain stem. In addition, it can cause hydrocephalus by causing obstruction in the circulation pathways of cerebrospinal fluid (CSF) (3). Most of these tumors need to be treated urgently and the risk of morbidity and mortality is high (4).

In this study, the clinical and radiological findings, early surgical results, and complication rates of children that were treated for a malignant tumor located in the posterior fossa were investigated in our clinic.

\section{Materials and Methods}

This retrospective study was made with the decision of the local ethics committee numbered 2020.06.2.01.085. For the study, written and verbal consent was obtained from the families.

Between 2011 and 2020, there were 76 consecutive children treated in our clinic due to brain tumors. Of these, 35 were diagnosed as malignant posterior fossa tumors. The data of these 35 patients were analyzed by scanning from the hospital archive system. Two patients were excluded from the study because their data were insufficient. Patients at the age of 18 years and older and children with supratentorial tumors and infratentorial benign tumors were excluded from the study. For all 33 children, age, gender, symptoms, clinical signs, whether they were operated, the timing of surgery, whether external ventricular drainage (EVD) and/or ventriculoperitoneal (VP) shunt was inserted, type of tumor, grade, Ki-67 index, neurological status, early surgical complications, and results when leaving the hospital were recorded. Preoperative and postoperative magnetic resonance imagings and computed tomography were scanned. Tumor localization, whether there was a cyst or bleeding, presence of hydrocephalus, tumor removal rate (total if $100 \%$ removed; subtotal if removed $90 \%$ and above; partial if removed below 90\%), and the presence of blood in the postoperative ventricles were evaluated by the same specialist doctor.

\section{Statistical Analysis}

Nominal variables were compared using the Fisher's exact test or chi-square test, according to the number of subjects. The F test was used to evaluate the distribution characteristics of countable variables, which were compared with the Student's t-tests. A p-value of $<0.05$ was considered significant.

\section{Results}

\section{Clinical Features}

The median age of 33 children was 7 years (17 months-17 years; min-max). Girl to boy ratio was $18 / 15$. The patients were divided into 4 different groups by age: those younger than 3 years old (21.4\%), those at the age range of 3-6 years (24.2\%), those at the age range of 6-10 years (27.3\%), and those at the age over 10 years $(27.3 \%)$. The most common symptoms of admission were headache $(57.6 \%)$ and gait disturbance $(48.5 \%)$. Four patients were brought to the emergency service due to epileptic seizures. Papilledema, ataxia, and nystagmus were frequently observed in the examination findings of the children. Six patients had preoperative cranial nerve paralysis. Of these, 3 patients had abducens nerve, 1 patient had the oculomotor nerve, 1 patient had the facial nerve, and 1 patient had hypoglossal 
nerve paralysis. All three patients had extremity weakness (Table 1).

\section{Pathology and Surgery}

The most common tumor was medulloblastoma (39.4\%). Then, diffuse pontine glioma, ependymoma, pilocytic astrocytoma were seen, respectively. One patient had hemangioblastoma and 1 patient had Ewing sarcoma/ primitive neuro-ectodermal tumors (PNET) (Table 2). The rate of World Health Organization Grade III and IV tumors among the operated tumors was $66.7 \%$. All of the patients were operated on prone position. Tumor resection was performed in 24 patients without diffuse pontine glioma (Table 3). Total removal was achieved in half of the patients who underwent tumor resection. Three of the subtotally removed tumors (patient no: $5,15,22$ ) were operated again within 24 hours and removed totally. Endoscopic third ventriculostomy (ETV) was performed in one of the patients with pontine glioma. $52 \%$ of 25 patients who underwent

Table 1. The rates of 33 patients' symptoms and signs

\begin{tabular}{lcc} 
& $\mathbf{n}$ & Percentage \\
\hline Symptom & 19 & 57.6 \\
Headache & 16 & 48.5 \\
Gait disturbance & 13 & 39.4 \\
Vomiting & 5 & 15.2 \\
Dizziness & 4 & 12.1 \\
Seizure & 2 & 6.1 \\
Diplopia & 2 & 6.1 \\
Weakness & & \\
Signs & 23 & 69.7 \\
Papilledema & 22 & 66.7 \\
Ataxia & 17 & 51.5 \\
Nystagmus & 12 & 36.4 \\
Dysmetria & 6 & 18.2 \\
Cranial nerve palsy & 6 & 18.2 \\
Dysdiadochokinesia & 3 & 9.1 \\
Paresis & 2 & 6.1 \\
Dysarthria & &
\end{tabular}

\begin{tabular}{lcc} 
Table 2. Distribution of tumors & & \\
& $\mathbf{n}$ & Percentage \\
\hline Medulloblastoma & 13 & 39.4 \\
Diffuse pontine glioma & 9 & 27.2 \\
Ependymoma & 5 & 15.2 \\
Pilocytic astrocytoma & 4 & 12.2 \\
Hemangioblastoma & 1 & 3 \\
Ewing sarcoma/PNET & 1 & 3 \\
\hline
\end{tabular}

PNET: Primitive neuro-ectodermal tumors surgery were operated under emergency conditions. EVD was inserted into 10 (30.3\%) of all patients (one with diffuse pontine glioma). Only 4 of them needed VP shunts (one of them diffuse pontine glioma).

\section{Complications}

The rate of development of any surgical complications in Grade III and Grade IV tumors was 13/18 and was significantly higher compared to low-grade tumors $(\mathrm{p}=0.038)$. The complication rate in totally removed tumors was also significantly higher than subtotally removed ones $(\mathrm{p}=0.034)$. There was no statistical relationship between age, gender, tumor size, timing of surgery and complication development $(\mathrm{p}=0.362$, $\mathrm{p}=0.653, \mathrm{p}=0.552, \mathrm{p}=0.613$, respectively). The most common complication was CSF fistula (16.7\%). Only 1 patient with CSF fistula was operated due to dura repair. Three patients with EVD had signs of infection. Staphylococcus epidermidis and Stenotrophomonas maltophilia were grown in the CSF culture samples. All 3 patients healed with antibiotic therapy. Three patients had a postoperative hematoma at the tumor site (one of the epidural hematoma), these patients were re-operated due to hematoma evacuation. Hydrocephalus developed in two patients $(8.3 \%)$ who did not receive EVD in the early postoperative period and VP shunts were inserted in these patients. Four of 6 patients with VP shunt inserted had postoperative intraventricular blood. Postoperative hemiparesis developed in two patients without previous weakness. Three patients (12.5\%) had mutism and one patient had dysarthria. Two children had pneumonia during intensive care follow-up, one of whom died two months after surgery.

\section{Discussion}

Posterior cranial fossa has a very limited volume compared to the supratentorial area. It has a brain stem, cerebral aqueduct, $4^{\text {th }}$ ventricle, outlet foramens and cerebellum. A growing posterior fossa tumor can lead to the dysfunction of the structures in this region in a short time, causing brain stem and cerebellar findings. In addition, they can cause herniation or hydrocephalus with the mass effect and edema (2). In our series, 22 patients had preoperative hydrocephalus. Thirteen of these patients were operated urgently. Three of these 13 patients were also in the herniation table. Partanen et al. (5) reported the EVD rate as 10/22 after the posterior fossa tumors they operated, and our EVD rate was similar. 
Table 3. Early surgical results and complications of patients undergoing tumor resection

\begin{tabular}{|c|c|c|c|c|c|c|c|c|c|c|}
\hline No & $\begin{array}{c}\text { Age } \\
\text { (years) }\end{array}$ & Gender & Pathology & $\begin{array}{c}\mathrm{Ki}-67 \\
(\%)\end{array}$ & $\begin{array}{c}\text { Preoperative } \\
\text { hydrocephalus }\end{array}$ & $\begin{array}{c}\text { Tumor } \\
\text { removal rate }\end{array}$ & EVD & Shunt & Complications & $\begin{array}{l}\text { Result } \\
\text { (GCS) }\end{array}$ \\
\hline 1 & $17 \mathrm{~m}$ & $\mathrm{G}$ & $\begin{array}{c}\text { Anaplastic } \\
\text { ependymoma }\end{array}$ & 30 & $\mathrm{Y}$ & $\begin{array}{c}\text { Subtotal } \\
(95 \%)\end{array}$ & Y & Y & $\begin{array}{c}7^{\text {th }} \text { nerve paralysis, } \\
\text { hematoma }\end{array}$ & 15 \\
\hline 2 & $17 \mathrm{~m}$ & $\mathrm{G}$ & Medulloblastoma & 15 & $\mathrm{Y}$ & $\begin{array}{l}\text { Subtotal } \\
(90 \%)\end{array}$ & Y & $\mathrm{N}$ & Pneumonia & $3(e x)$ \\
\hline 3 & $18 \mathrm{~m}$ & B & $\begin{array}{c}\text { Anaplastic } \\
\text { ependymoma }\end{array}$ & 30 & $\mathrm{~N}$ & Total & $\mathrm{N}$ & $\mathrm{N}$ & $\begin{array}{c}\text { Pneumonia, } \\
\text { hemiparesis, } 9^{\text {th }} \text { nerve } \\
\text { paralysis }\end{array}$ & 15 \\
\hline 4 & $20 \mathrm{~m}$ & B & $\begin{array}{c}\text { Pilocytic } \\
\text { astrocytoma }\end{array}$ & 3 & $\mathrm{~N}$ & Total & $\mathrm{N}$ & $\mathrm{N}$ & None & 15 \\
\hline 5 & $21 \mathrm{~m}$ & B & Ependymoma & 12 & $\mathrm{Y}$ & $\begin{array}{l}\text { Subtotal } \\
(90 \%)\end{array}$ & $\mathrm{N}$ & $\mathrm{Y}$ & $\begin{array}{c}\text { CSF fistula, } \\
\text { hydrocephalus }\end{array}$ & 15 \\
\hline 6 & $29 \mathrm{~m}$ & $\mathrm{G}$ & $\begin{array}{c}\text { Anaplastic } \\
\text { ependymoma }\end{array}$ & 20 & $\mathrm{Y}$ & Partial (80\%) & Y & $\mathrm{N}$ & $\begin{array}{l}\text { Infection, } 6^{\text {th }} \text { nerve } \\
\text { paralysis }\end{array}$ & 15 \\
\hline 7 & 3 & $\mathrm{G}$ & $\begin{array}{l}\text { Ewing sarcoma/ } \\
\text { PNET }\end{array}$ & 20 & $\mathrm{Y}$ & Partial (70\%) & Y & $\mathrm{N}$ & Epidural hematoma & 15 \\
\hline 8 & 5 & $\mathrm{G}$ & $\begin{array}{c}\text { Anaplastic } \\
\text { ependymoma }\end{array}$ & 70 & $\mathrm{Y}$ & Total & $\mathrm{N}$ & $\mathrm{N}$ & None & 15 \\
\hline 9 & 5 & $\mathrm{G}$ & $\begin{array}{c}\text { Pilocytic } \\
\text { astrocytoma }\end{array}$ & 4 & Y & $\begin{array}{l}\text { Subtotal } \\
(95 \%)\end{array}$ & Y & $\mathrm{N}$ & None & 15 \\
\hline 10 & 6 & $\mathrm{G}$ & Medulloblastoma & 80 & $\mathrm{~N}$ & Total & $\mathrm{N}$ & $\mathrm{N}$ & None & 15 \\
\hline 11 & 6 & $\mathrm{G}$ & Medulloblastoma & 18 & $\mathrm{Y}$ & $\begin{array}{l}\text { Subtotal } \\
(95 \%)\end{array}$ & $\mathrm{N}$ & $\mathrm{N}$ & CSF fistula & 15 \\
\hline 12 & 7 & B & $\begin{array}{c}\text { Pilocytic } \\
\text { astrocytoma }\end{array}$ & 3 & $\mathrm{Y}$ & Partial (70\%) & $\mathrm{N}$ & $\mathrm{Y}$ & Mutism, hydrocephalus & 15 \\
\hline 13 & 7 & $\mathrm{G}$ & Medulloblastoma & 40 & $\mathrm{Y}$ & $\begin{array}{l}\text { Subtotal } \\
(90 \%)\end{array}$ & $\mathrm{N}$ & $\mathrm{N}$ & None & 15 \\
\hline 14 & 7 & B & Medulloblastoma & 30 & $\mathrm{Y}$ & Total & $\mathrm{N}$ & $\mathrm{N}$ & Mutism, CSF fistula & 15 \\
\hline 15 & 8 & B & Medulloblastoma & 30 & $\mathrm{Y}$ & Partial (80\%) & $\mathrm{Y}$ & $\mathrm{Y}$ & CSF fistula, infection & 15 \\
\hline 16 & 8 & B & Medulloblastoma & 70 & $\mathrm{Y}$ & Total & $\mathrm{N}$ & $\mathrm{N}$ & $\begin{array}{l}6^{\text {th }} \text { and } 7^{\text {th }} \text { nerve } \\
\text { paralysis }\end{array}$ & 15 \\
\hline 17 & 11 & G & Medulloblastoma & 80 & Y & Total & $\mathrm{N}$ & $\mathrm{N}$ & None & 15 \\
\hline 18 & 11 & $\mathrm{G}$ & Medulloblastoma & 9 & Y & Total & $\mathrm{N}$ & $\mathrm{N}$ & None & 15 \\
\hline 19 & 12 & $\mathrm{G}$ & Medulloblastoma & 60 & $Y$ & Total & $\mathrm{N}$ & $\mathrm{N}$ & $\begin{array}{l}6^{\text {th }} \text { and } 7^{\text {th }} \text { nerve } \\
\text { paralysis, hemiparesis }\end{array}$ & 15 \\
\hline 20 & 13 & B & $\begin{array}{c}\text { Pilocytic } \\
\text { astrocytoma }\end{array}$ & 2 & $\mathrm{~N}$ & Total & $\mathrm{N}$ & $\mathrm{N}$ & None & 15 \\
\hline 21 & 14 & B & Medulloblastoma & 70 & $\mathrm{Y}$ & Total & Y & $\mathrm{Y}$ & $\begin{array}{l}\text { Mutism, infection, } 9^{\text {th }} \\
\text { nevre paralysis }\end{array}$ & 15 \\
\hline 22 & 15 & $\mathrm{G}$ & Medulloblastoma & 20 & $\mathrm{Y}$ & Partial (70\%) & Y & $\mathrm{N}$ & Mutism, dysarthria & 15 \\
\hline 23 & 15 & $\mathrm{G}$ & Hemangioblastoma & 1 & Y & Total & $\mathrm{N}$ & $\mathrm{N}$ & None & 15 \\
\hline 24 & 17 & B & Medulloblastoma & 80 & $\mathrm{Y}$ & Partial (80\%) & Y & $\mathrm{N}$ & Hematoma & 15 \\
\hline
\end{tabular}

M: Months, G: Girl, B: Boy, Y: Yes, N: No, EVD: External ventricular drainage, GCS: Glasgow Coma scale, CSF: Cerebrospinal fluid, PNET: Primitive neuro-ectodermal tumour

The classic symptoms of posterior fossa tumors are irritability, lethargy, nausea, vomiting, headache, and behavioral changes with increased intracranial pressure (6). Our patients had similar symptoms and in addition, four patients had epilepsy. In a study, clinical signs were most commonly reported as ataxia, papillary stasis, dysmetria, and dysdiadokinesia (7). In our series, $51 \%$ of patients had nystagmus and $18 \%$ had cranial nerve palsy.

Yağcı Küpeli et al. (8) reported that the median age was 8 years in childhood tumors similar to ours. In the same study, it was reported that tumors were more common in males in all age groups. Similarly, Erdinçler et al. (4) found 
the proportion of boys as $66 \%$. However, in our series, posterior fossa tumors were more common in girls.

The most common types of tumors found in the posterior fossa are cerebellar astrocytomas, medulloblastomas, and brainstem gliomas (1). The most common tumors in our patients were medulloblastoma and diffuse brainstem glioma. Medulloblastoma rate was most common, similar to the literature. Abraham et al. (9) $51.3 \%$ and Lee et al. (10) reported it as 35.9\%. However, Yağcı Küpeli et al. (8) reported as $7.9 \%$ and Shanmugavadivel et al. (11) as $10.9 \%$ among the posterior fossa tumors, and these rates are lower than our study. In addition, one of our patients had Ewing sarcoma/PNET, which is rare in the posterior fossa, and was urgently operated due to left cerebellar hemisphere compression and hydrocephalus (Figure 1). It has been reported that ependymomas are more common in males in childhood and its rate in the posterior fossa is $5.2 \%(5,12)$. It was $15.6 \%$ in our study, but more in girls. Cerebellar astrocytomas are benign tumors of the central nervous system. It constitutes $30 \%$ of childhood posterior fossa tumors (13). In our patients, the rate of pilocytic astrocytoma was lower than in other series.

Diffuse pontine gliomas have a poor prognosis. Surgical treatment has been abandoned in the treatment of diffuse pontine gliomas. However, a stereotaxic biopsy can be performed for collecting samples from the tumor. In patients with brainstem lesions, the postoperative morbidity of stereotactic biopsy has been reported between 0 and $20 \%$ and mortality between 0 and $3 \%$ (14). Children with diffuse pontine glioma treated in our clinic did not undergo any surgery for the tumor. Patients were followed up by pediatric oncology. One of the patients underwent EVD and then VP shunt due to acute hydrocephalus. ETV was performed on another patient.

Depending on the type of tumor, tumor localization may vary. It has been reported that tumors in the posterior fossa are mostly located in vermis localization (5). In our series, although tumors were more common in vermis origin, the rate of tumors in the fourth ventricle was higher. This was because the tumor reached a large volume and filled the fourth ventricle in a high proportion of patients. Lee et al. (10) reported the rate of tumors with extensive cerebellum and brain stem as $43.6 \%$. This was in a quarter of our patients. Two of our patients whose tumors were totally removed had postoperative hemiparesis and these children had brainstem invasion. In another aspect, invasion into the brainstem was the most important reason for total resection of the tumor. Three of our patients were re-operated due to residual tumors. In a study with 22 patients, it was reported that 2 patients were operated twice, and 1 patient was operated three times (5). In 3 of our patients, there was postoperative bleeding in the tumor site and they were re-operated. Ur-Rehman et al. (15) gave this rate as $3.8 \%$.

Partanen et al. (5) reported that at least one complication developed in 19 out of 22 patients. In our patients, this rate was 15/24 and most of the complications occurred in high-grade tumors. Ur-Rehman et al. (15) reported that in 79 infratentorial tumors they operated, the most common surgical complications were hydrocephalus and CSF fistula. Similarly, we saw the most common complication was CSF fistula. However, only one patient had to repair the dura mater. Bilginer et al. (13) reported CSF fistula in $6.4 \%$ of patients after 31 pilocytic astrocytoma operations.
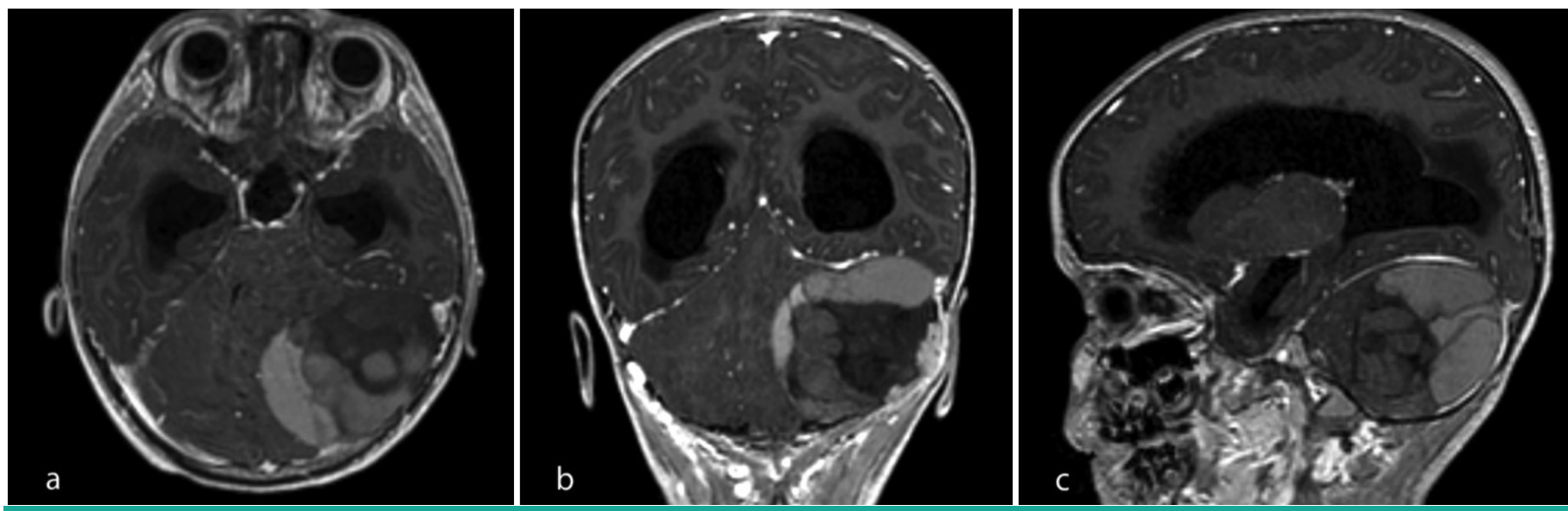

Figure 1. Contrasted MRIs of the patient with Ewing sarcoma/PNET tumor; a) axial, b) coronal, c) sagittal sections

MRI: Magnetic resonance imagings, PNET: Primitive neuro-ectodermal tumors 
VP shunt or ETV application has been reported at different rates due to hydrocephalus in various series. Lee et al. (10) reported the rate of patients developing postoperative permanent hydrocephalus as $61.5 \%$. In another study, they reported this rate as $9.4 \%$ (9). In the same study, being under the age of six years and the presence of intraventricular blood were shown as risk factors for hydrocephalus. One-quarter of our operated patients had VP shunts inserted and patients who needed shunt had a high rate of intraventricular blood.

The rate of wound infection in posterior fossa surgery has been reported around $6 \%(15)$. In our series, there were no children with wound infections. Abraham et al. (9) stated that 4 of 14 patients requiring shunts had meningitis and two patients developed staphylococcus in the CSF culture. In our series, there were 3 cases showing signs of meningitis. VP shunts were inserted into two of them due to hydrocephalus. In addition, 2 patients were diagnosed with pneumonia during intensive care follow-up and a child died due to this reason in the second postoperative month. Aslantürk et al. (3) reported death rate as $20 \%$ in the early postoperative period and reported that two of them were due to surgical air embolism in a sitting position. We operated all patients in the prone position and did not see air embolism.

One of the complications that occur after posterior fossa tumor surgery is mutism. Cámara et al. (16) reported cerebellar mutism at a rate of 19/36. Gora et al. (17) gave this rate as $18.2 \%$ in 33 children with midline posterior fossa tumors. In the same study, they identified medulloblastoma, maximum size $>45 \mathrm{~mm}$ tumor, superior cerebellar peduncle, and middle vermian incision as risk factors for mutism. Three patients who developed mutism from our patients had midline tumors, all of them were operated with vermian incision, and two had cerebellar peduncle involvement. Studies have shown that there may be findings accompanying mutism such as ataxia, dysarthria, and facial nerve palsy (18). One of our patients who developed mutism had difficulty swallowing, and another had dysarthria after mutism. In addition, another patient with anaplastic ependymoma had difficulty swallowing. Lee et al. (10) have stated that this complication is seen more than known. Children who were operated for 183 posterior fossa tumors were examined with videofluoroscopic swallowing study in the early period, and 39 of them had postoperative swallowing difficulty. In the same study, the most important risk factor for difficulty swallowing was shown as brain stem invasion.
The limitations of this study are its retrospective design, low number of patient group, insufficient long-term surgical follow-up, and evaluation of chemotherapy and radiotherapy treatments. Having more information about tumor biology, advances in imaging methods and microsurgical techniques, and prospective clinical studies will reduce morbidity and mortality in the future for children with posterior fossa tumors.

\section{Conclusion}

In our study, high-grade tumor, brainstem invasion, total tumor removal, and intraventricular blood increased the risk of complications in children. Total resection should be aimed for posterior fossa tumors, but it should be noted that the rate of morbidity increases as the resection amount increases in patients with brainstem invasion. Our goal in the treatment of these children should be to improve long-term quality of life, to maintain cognitive function and growth, to minimize complications, and to reduce the risk of secondary malignancies in the course of the disease.

\section{Ethics}

Ethics Committee Approval: Ethical approval was obtained from the University of Health Sciences Turkey, Bağcılar Training and Research Hospital Ethical Committee (decision number: 2020.06.2.01.085).

Informed Consent: For the study, written and verbal consent was obtained from the families.

Peer-review: Externally peer-reviewed.

\section{Authorship Contributions}

Concept: B.E., Design: B.E., Data Collection or Processing: B.E., İ.G., Analysis or Interpretation: N.S.B., Writing: B.E., İ.G., N.S.B.

Conflict of Interest: No conflict of interest was declared by the authors.

Financial Disclosure: The authors declared that this study has received no financial support.

\section{References}

1. Bereket A. Endocrinologic consequences of pediatric posterior fossa tumours. J Clin Res Pediatr Endocrinol 2015;7(4):253-259.

2. Kızılkılıç O, Çallı C. Radiology in posterior fossa tumors. Türk Nöroşir Derg 2017;27(1):8-23.

3. Aslantürk Y, Yılmaz N, Ökten Aİ, Akbay FY, Basmacı M, Taşkın Y. Surgical treatment results in posterior fossa tumors. Van Tip Derg 2006;13(1):4-8. 
4. Erdinçler P, Dalgııç A, Tüzgen S, Çıplak N, Oral Z, Kuday C. Posterior fossa tumors in children: Analysis of 73 cases. Türk Nöroşir Derg 2002;12(1):31-39.

5. Partanen M, Bouffet E, Laughlin S, Strother D, Hukin J, Skokic J, et al. Early changes in white matter predict intellectual outcome in children treated for posterior fossa tumors. Neuroimage Clin 2018;20:697-704.

6. Millard NE, De Braganca KC. Medulloblastoma. J Child Neurol 2016;31(12):1341-1353.

7. Sönmez MA, Tekiner A, Bayar MA, Yılmaz A. Posterior Fossa İntraaksiyel Tümörlerinin Retrospektif İncelenmesi Retrospective Study of Intra axial Posterior Fossa Tumors. Kocatepe Tıp Derg 2012;13:133-137.

8. Yağcı Küpeli B, Ökten Aİ, Gezercan Y, Uluç Ş, Menteş S. Pediatric central nervous system tumors: retrospective analysis of 60 cases. Cukurova Med J 2018;43(4):931-935.

9. Abraham AP, Moorthy RK, Jeyaseelan L, Rajshekhar V. Postoperative Intraventricular Blood: A New Modifiable Risk Factor for Early Postoperative Symptomatic Hydrocephalus in Children With Posterior Fossa Tumors. Childs Nerv Syst 2019;35(7):1137-1146.

10. Lee WH, Oh BM, Seo HG, Kim SK, Phi JH, Chong S, et al. Oneyear outcome of postoperative swallowing impairment in pediatric patients with posterior fossa brain tumor. J Neurooncol 2016;127(1):73-81.

11. Shanmugavadivel D, Liu JF, Murphy L, Wilne S, Walker D. Accelerating diagnosis for childhood brain tumours: an analysis of the HeadSmart UK population data. Arch Dis Child 2020;105(4):355-362.
12. Rudà R, Reifenberger G, Frappaz D, Pfister SM, Laprie A, Santarius $\mathrm{T}$, et al. EANO guidelines for the diagnosis and treatment of ependymal tumors. Neuro Oncol 2018;20(4):445-456.

13. Bilginer B, Narin F, Oguz KK, Uzun S, Soylemezoglu F, Akalan N. Benign cerebellar pilocytic astrocytomas in children. Turk Neurosurg 2011;21(1):22-26.

14. Kuzan-Fischer CM, Souweidane MM. The intersect of neurosurgery with diffuse intrinsic pontine glioma. J Neurosurg Pediatr 2019;24(6):611-621.

15. Ur-Rehman ZU, Kahn MM, Ul-Haq MI. Complications Following Posterior Fossa Tumour Surgery in Children: Experience from a Tertiary Care Neurosurgical Facility in a Developing Country. Pak J of Neurol Surg 2018;22(4):177-182.

16. Cámara S, Fournier MC, Cordero P, Melero J, Robles F, Esteso B, et al. Neuropsychological Profile in Children with Posterior Fossa Tumors with or Without Postoperative Cerebellar Mutism Syndrome (CMS). Cerebellum 2020;19(1):78-88.

17. Gora NK, Gupta A, Sinha VD. Cerebellar Mutism Syndrome following Midline Posterior Fossa Tumor Resection in Children: An Institutional Experience. J Pediatr Neurosci 2017;12(4):313-319.

18. Küpeli S. Posterior Fossa Syndrome. Arch Med Rev J 2013;22(3):393407. 